v. 7, n.3

Vitória-ES, sept. - dec. 2010.

p. 1 - 22 ISSN 1808-2386 DOI: http://dx.doi.org/10.15728/bbr.2010.7.3.1

\title{
Systematic risk variations (beta) convertible debenture brazilian companies
}

\author{
Renata Drumond Pinto Coelho Antonino ${ }^{\dagger}$ \\ PRODABEL \\ Wagner Moura Lamounier ${ }^{\Omega}$ \\ Federal University of Minas Gerais - UFMG \\ Roberto Kaehler de Albuquerque Maranhão ${ }^{¥}$ \\ Independent Consultant
}

SUMMARY: The purpose of this article is to analyze the impact of issuing convertible debentures on the systematic risk of Brazilian companies. Some applied researches in the U.S. capital market (STEIN, 1992; LEWIS et al, 2002; RAI, 2005) indicate that convertible debentures may be used as an alternative financing source when adverse selection problem makes stock issuing unattractive financing source. The analysis of Brazilian companies that issued convertible debentures recorded in the period from 1998 to 2006 and that presented liquidity on the market indicated that variation in beta, on average, is positive. These results are coherent with the signaling hypothesis and with the absence of convertible debenture issuing in 2005 and 2006 on the Brazilian market. They also may be related to the precarious financial situation of issuing companies, observed by the analysis of some financial indicators in year of issue and in two pre- e post-issuing years.

Keywords: Hybrid titles, convertible debentures, systematic risk (beta), adverse selection, signaling.

${ }^{\dagger}$ Master in Administration by the Federal University of Minas Gerais Affiliation: Strategic Resource Analyst - PRODABEL

Address: Rua Oscar Trompowsky, $\mathrm{n}^{\circ}$ 1221, 1001, Gutierrez, Belo Horizonte/ MG, 30.441-123

E-mail: rdrumondp@yahoo.com.br Telephone: ( 31 ) 8497-4727

\footnotetext{
${ }^{\Omega} \mathrm{Ph}, \mathrm{D}$. in Applied Economics by the Federal University of Viçosa Affiliation: Associate Professor of the Federal University of Minas Gerais Address: Faculdade de Ciências Econômicas da UFMG. Av. Antônio Carlos, 6627 - Sala 2036 - Pampulha Belo Horizonte -MG. CEP: 31270-901 E-mail: wagner@face.ufmg.br Telephone: (31) 3409-7058
}

\footnotetext{
Master in Administration by the Federal University of Minas Gerais Affiliation: Independent Consultant Address: Rua Santo Agostinho, $\mathrm{n}^{\circ}$ 567, 1001, Belo Horizonte / MG, 31.035-480

E-mail: roberto@maranhaoconsultoria.com.br Telephone: (31) 8482-4456
} 


\section{INTRODUCTION}

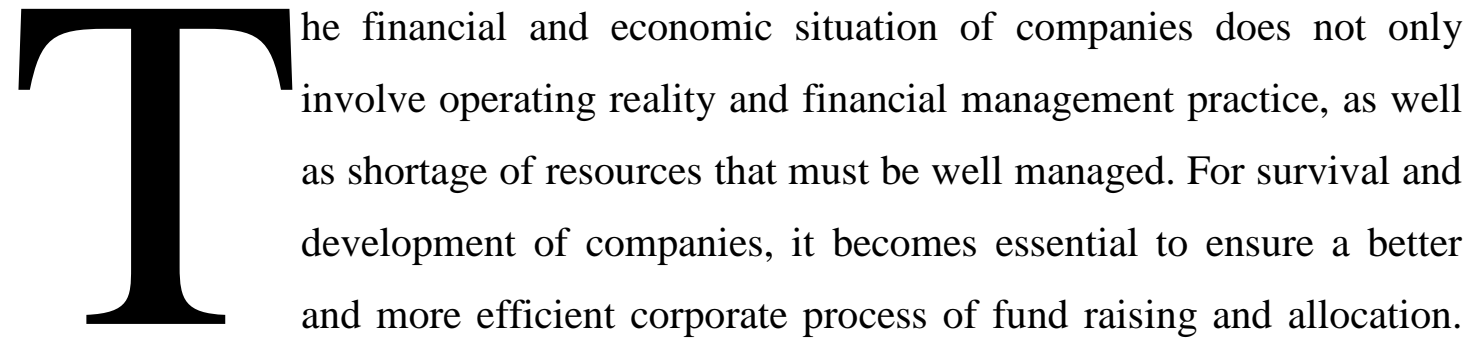

Investment and financing decisions may represent, therefore, the guidelines of the path to success or failure of companies, defining their position in the market.

According to Procianoy and Veisman (2000), as debentures are debt securities issued by companies that need long-term resources and, therefore, represent a source of financing, which may be placed with the end investor, which is not possible for other debt types. In this manner, the authors define debentures as financial instruments launched to raise funds directly placed with the investing public. Debentures convertible into shares, which convertibility clause must be described in the debenture deed, may be exchanged for issuer's shares.

Rozenbaum (2004) defines convertible debentures as hybrid securities that combine compensation of simple debentures with possible valuation of the shares for which simple debenture holder may exchange the convertible security. To Hull (1998), convertible securities are debt instruments with built-in options, being that the holder of such securities has the right to exchange them for shares of issuing company at certain times in the future, in accordance with a conversion defined in the deed.

Simão (2006) underscores that companies, normally, issue hybrid securities aimed at reducing financing cost, since convertible debentures have lower compensation (interest) than simple debentures. In spite of this potential advantage, it cannot be asserted that such cost reduction implies creation of value to shareholders. Value creation may occur when the company is able to adjust its corresponding liabilities to payment of principal until the maturity of convertible debentures. Otherwise, financial risk increase may cause strong stock price deterioration and, consequently, in the company's value.

Some studies (STEIN, 1992; MAYERS, 1998; LEWIS et al, 2002; RAI, 2005) sought to assess the impact of issuing convertible debentures on the beta of companies' shares and concluded that issuing convertible debentures, in addition to reducing agency and adverse selection costs, could reduce the beta of issuing companies. In these studies, some inferences about beta variation were based on the assumption that funds obtained by issuing would be 
used for financing new projects. Thus, convertible debentures could provide a lower cost for financing these projects in comparison to alternatives such as stock issuing. Additionally, the future conversion option would allow the manager to avoid additional issuing costs if the project were financed by stock issuing sequential or to avoid overinvestment if simple debentures had been issued in all stages of the project.

Rai (2005) examined systematic risk variation of convertible debenture issuing companies by measuring beta variation. He found evidences that, around the convertible debenture issuing period, the systematic risk of studied companies underwent changes, it being that, on average, such changes were negative, although there was significant heterogeneity of results among companies (about $40 \%$ of the companies had increase in beta).

To that end, the purpose of this paper is to apply Rai's approach (2005) to analyze the impact of issuing convertible debentures on the systematic risk of Brazilian issuing companies.

Section 2 of this paper highlights the development of the Brazilian debenture market, signaling and adverse selection theories, as well as a brief literature review of the impacts of issuing convertible debentures on the risk stock issuing companies. Section 3 covers the methodological aspects of the investigation, detailing research methods used.

In Section 4, the results obtained through beta variation analysis are discussed. Further in this section, a general financial analysis of issuing companies is presented, by interpreting some financial indicators and their variation during the period that covers two prior years and two subsequent years to issuing recording date (zero date). Final considerations about the issue dealt with in this article are presented in section 5.

\section{THEORETICAL REFERENTIAL}

\subsection{Brazilian debenture market development}

\subsubsection{Origin}

Debentures have already been set forth in the Brazilian commercial code and corporation legislation since 1822. After proclamation of the Republic, in 1889, there was a cycle of euphoria and speculation known as wild speculation (1889-1891), where using bearer papers with no technical backing was intensive. According to Bovespa (2003), this period had as one of its unfolding Decree No. 177-A/1893, known as the "Debenture Loan Law". Such decree remains valid up to the early 60s. It was supplemented by Decree No. 22.431, of 1933 and Decree-law No. 781, of 1938. Despite the existence of referred regulations, the debenture 
market, at that time, had little expressiveness, in view of the nonexistence of protection mechanisms from the effects of inflation in long-term investments.

Bovespa (2003) highlights other laws that are fundamental to the historic report of the debenture market, such as Law 4,728, of 1965, which introduced important innovations to debentures, such as the possibility of conversion into shares and indexation; and Law 6,404/76, which allowed debentures to take on the form that prevails currently. Law 6,404/76 was amended by Law 10,303/01. Law 6,385/76, in turn, created the CVM and disciplined the capital market, bringing greater security to investors, being subsequently amended by Law $9,457 / 97$.

According to Kimura (2003), between 1976 and 1993, some innovations in the debenture market stand out, such as: (1) expansion of debenture kinds, (2) new issuing limits tied to guarantees, (3) creation of limitless subordinated debenture, (4) permission of issuing tied to foreign currency with possibility of placement, (5) creation of the trust agent figure, (6) definition of registration standards by CVM, (7) creation of subscription bonus as an additional primary market advantage and (8) assignment of CVM as a market regulatory agency.

However, as Simão (2006) emphasizes, the years that preceded the Real Plan (created in 1994) were marked by an extended period in which Brazilian economy was characterized by high inflation rates. In this period, there were several attempts to reduce inflation rates by unsuccessful launchings of economic stabilization plans and high economic growth rate volatility measured by national GDP (gross domestic product) evolution. Within this context, the environment did not favor the development of a sustainable medium-term economic growth trajectory and, consequently, it did not allow the development of the Brazilian capital market on solid, long-term bases.

According to Ribeiro (2002), in spite of the existence of economic order factors that might stimulate he debenture market development in the $80 \mathrm{~s}$, there were market growth limiters. As stimulating factors, the following stand out: (1) beginning of subsidized credit elimination, (2) Tax rate increase of the tax on financing credit operations maintain exemption on operations with debentures, (3) monetary policy release, (4) leverage restrictions on financial institutions and (5) flexibility of open capital company registration rules.

The restrictions imposed by Resolutions 756/82 and 794/83 of the National Monetary Council $(\mathrm{CMN})$, which prohibited debenture purchase by pension funds and commercial 
banks; and tax burden increase imposed by Decree Law 2071/83 (which taxed discount on debenture issuing) rendered market expansion difficult at the time. Furthermore, abolition of economic indexation imposed in Cruzado Plan in 1986 made issuing longer-term private securities impracticable when inflation returned.

In the 1980s, therefore, the debenture market had an irregular behavior, due to constant changes to operating, taxation rules and indexers, many of them introduced by the several stabilization plans. Recovery only occurred at the end of the decade, when Summer Plan allowed using several indexes, which stimulated investors. However, this recovery did not last long, having in view, mainly, the recessive e economic policy of 1990-1991, considerably diminishing the domestic capital market growth rate.

\subsubsection{Post-real plan development}

Provisional Measure No. 434, of February 28, 1994, created Unit of Real Value URV, which would later be transformed into the Brazilian currency, the Real, which was introduced by the monetary reform of July 1, 1994, initially consolidated in Provisional Measure No. 542. The following phase, of new recovery, is related to the Real Plan.

According to Procianoy and Veisman (2000), Real Plan may be considered as turning point in preparation of Brazilian debenture deeds, mainly by the strong impact of inflation reduction on the prevailing clauses in these issues. Such impact defined important changes to the microstructure characteristics of debentures used by Brazilian companies, such as maturity, amortization clauses and advance redemption, rescheduling, among others.

As far as debenture-related legislation is concerned, the authors further highlight that, after March 1990, when Collor Plan occurred, identification of investors in the financial market became mandatory and debentures were restricted to nominative modality (ANDIMA and ABRASCA, 2002).

Andima (National Association of Open Market Institutions) developed the SND (National Debenture System) in 1998, allowing electronic processing of registration, custody and financial settlement of operations. The introduction of SND stimulated utilization growth of debenture as an alternative source of funding, as well as it stimulated financial instrument upgrade (KIMURA, 2003).

Filgueira and Leal (2000) underscore that the debenture Brazilian market, due to the country's Post-Real Plan economic restructuring and the several configuration possibilities of 
the debit/credit relation, have been presenting high growth, both in volume and amount (new modalities added to those existing and used).

In 2001, Bovespa Fix was created, which is Bovespa electronic trading system of fixed income bonds, the purpose of which is to foster liquidity and transparence increase in security trading. The main available products for investment by an individual traded on Bovespa Fix are debentures and CRIs (Certificates of Real Estate Receivables), which are securities, issued by securitization companies and have real estate receivables as collateral.

In 2002, the Committee for Capital Market Development (Codemec) was created, which aims to promote and hold study debate, projects and prioritized proposals for the capital market, based on the Capital Market Master Plan, by effort coordination of the 45 participating entities. Codemec also aims to seek support and performance of other nonCommittee participating national and international, but with potential in technical area, such as Universities, Pension Funds, World Bank, among others (FILGUEIRA, 2006).

CVM Instruction No. 400, of 12/29/03 gathered, in a single standard, rules on public offering, securities distribution in the primary and secondary markets registration procedure rules, revoking Instructions No. 13/80 and No. 88/88. The standard upgrades fund raising mechanisms and its purpose is to protect the interests of the investing public by fair treatment to offers and wide information disclosure.

In February 2004, soon after Instruction No. 400, CVM published Instruction No. 404, regulated debenture issuing with simplified registration procedure and standards of clauses and terms to be adopted in debenture issuing deeds designed for trading in a special stock exchange segment or organized over-the-counter market entities. However, since publication of the standard, no issue has been recorded by means of "standardized or simplified" modality.

\subsection{Signaling and adverse selection theories}

Many studies (STEIN, 1992; LEWIS et al, 2002; MAYERS, 1998; RAI, 2005) that explore market reaction before announcements of companies about their choices in relation to alternative sources of financing are based on the signaling and adverse selection theory, reactions in assets prices reflect market interpretations referring to the attitudes of issuing companies' managers. Managers are usually better informed than outside investors, and it is known as asymmetric information. In this manner, the attitudes of managers are interpreted by the market, by taking into consideration this information asymmetry. 
According to Matos (2001), signaling becomes essential in a world with asymmetry of information, where participants look for signs that indicate to them the best decision to be made. If managers and shareholders purchase company shares, there may be value assigned to this action, which becomes a sign of good perspective for the company.

The author further emphasizes that asymmetry of information may cause a greater offer of low quality projects. This would occur, because, as managers and shareholders would be better informed than investors might overvalue the quality of the project, causing investors to trust this investment and would realize too late the error made. Thus, capital cost for financing projects increases and many good projects end up not being financed.

According to Brigham and Ehrhardt (2006), in the theory of signaling, companies with very favorable perspectives are expected to avoid selling new shares and, instead, will try to increase their capital by other mains, including using debts. On the other hand, companies with unfavorable perspectives are expected to sell new shares, bringing new investors to share potential losses. Because of all of this, the announcement of a new share offering is usually understood negative sign and tends to depreciate the price of the share.

Likewise, the theory of adverse selection defends that managers should opt for selling new shares when they are overvalued and for repurchasing shares when they are undervalued. Leland and Pyle (1977) explain the company management has privileged information that determine an optimistic view of the future behavior of the company's cash flows and its market share, the logical choice of the source of financing will be issuing debt securities. On the other hand, if the management has poor future perspectives, the option will be for issuing new shares, since these will be overvalued at the time of issue comparatively to what is expected in relation to their future price.

According to Myers and Majluf (1984), if the company decides to make an investment without issuing shares for its financing there is a sign that the actual value of the assets in operation is higher than the value of shares. Thereby, issuing new shares will be a negative sign. Investors interpret as a positive sign of the true company value the decision not to issue new shares and, preferably, the decision to use own resources for financing. The hierarchy of the sources of financing is established from the conclusions of Myers and Majluf (1984), internal resources being, therefore, preferable to external ones and debt preferable to issuing shares, contradicts Jensen's hypothesis (1986) that shareholders would prefer a high level of indebtedness. 
According to Tirole (2005), the hypothesis known as pecking-order, developed in Myers and Majluf's paper (1984), defines that companies prefer to use internal resources (share capital, retained earnings) to finance their investments. If internal resources are insufficient and external resources are required, companies issue debts first, then hybrid securities, such as convertible debentures and, finally, as a last resort, shares.

Thus, the hierarchy of sources of financing, determined by pecking order, indicates that debt is the best source of external resources. Tirole (2005) points out that, according to the theory of adverse selection, companies are reluctant to issue common shares when they believe that their shares are undervalued, which means that the option for issuing new shares signals that managers consider that shares are in fair price or overvalued.

To Deangelo and Masulis (1980) companies that choose issuing debt securities as a source of financing may convey a dubious message to investors. This occurs because issuing debt securities at the same time when it may express a need for financial resources, being considered bad news to investors, may also represent financial leverage increase, which is good news to investors. The authors found evidences that the announcement of simple debentures simples produces no effect on the price of shares, whereas the announcement of convertible debentures, because it is an instrument with debt and shareholders' equity characteristics, produces a negative effect.

Lewis et al (1998) explain that theory of signaling suggest that the market's response to the announcement of convertible debenture issuing, will be, on average, negative. Since managers know more about the company's prospects than outside investors, and since they seek to maximize the wealth of current shareholders (not of potential), such managers are encouraged to issue new shares when they believe that the company is overvalued.

And, since part of the convertible security value consists of the option for the company's shares, the same is expected for convertible debentures, though to a lesser degree. In this manner, due to the asymmetry of information between managers and outside investors, companies face the adverse selection problem when they issue convertible debentures.

\subsection{Impacts of convertible debenture issuing on the risk of shares}

Ross et al (2002) define risk as the "unexpected portion of return", which results from surprises, there may be several sources of risk, some that affect all companies and others that affect specific companies only. Thus, risk is divided into two components: (1) systematic risk and (2) non-systematic or idiosyncratic risk. Systematic risk affects a large number of assets, 
each with greater or lesser intensity, such as, for example, risks related o the economic conditions in general, such as variations in interest rates or inflation.

Idiosyncratic risk, in turn, specifically affects a single asset or small group of assets, such as, for example, the risk that a company may have misjudged and requires from its customers a product or service (design risk); or risk of stronger or weaker competitors than predicted (competitive risk); or further, the so-called sector risk, which affects an entire sector. However, it is relevant to highlight that this distinction is not so accurate in practice, because, however limited and peculiar is news, it is impossible to assert accurately that it will not exert effects on the entire economy.

Ross et al (2002) further explain that the influence of a systematic risk may be represented by coefficient beta $(\beta)$, which reveals what the return sensitivity to return of the action to this risk is. Therefore, if the title of the company is positively related to certain systematic risk, this title will be beta positive. If it is negatively related, it has a beta negative and nil when there is no correlation.

The magnitude of beta describes the intensity of systematic risk impact on the returns of the title. A beta equal to +1 , for example, indicates that the title's return rate should vary in the same proportion as the systematic factor.

Lewis et al (2002) conducted a study intended to analyze risk variations around convertible debenture issuing. They sought to check that the drop in stock price after issuing the convertible security might be caused by an unexpected capital cost increase. They analyzed variations in financial leverage, in systematic risk, as well as in non-systematic risk and total risk.

The evidences of the study indicated a reduction in capital cost after issuing, which would be inconsistent with interpretation of the causal relation between the return drop and capital cost increase. There was an increase in financial leverage; however, a decline in systematic risk was verified. In relation to idiosyncratic risk, an increase was found in it after issuing.

Lewis et al (2002) emphasizes that, although idiosyncratic risk increase has no impact on issuer's capital cost, it may influence in the company's investment decisions, adversely impacting its performance.

To that end, it can be inferred that efficient investment decisions predicted by the theory, are not verified in practice, in the case of convertible debenture issuing companies. 
Lewis et al study (2002) supports the conclusions of Stein (1992) in relation to the fact that convertible securities reduce adverse selection agency costs. The hypothesis made by Stein (1992), called "back-door equity financing hypothesis" also defines that the systematic risk of the convertible debenture issuing company will diminish.

Rai (2005) examined the variations in systematic risk in a sample of 149 American companies when they issue convertible debentures. According to the author, variation in beta may result both from variation in financial leverage and non-leveraged beta variation, such as, for example, variations in the company's investment policies.

Thus, ceteris paribus, an increase in financial leverage will increase the beta of a company's shares. According to Damodaran (2004), non-leveraged beta (also called asset beta) will be determined by the kind of business that the company operates and by its operating leverage. In this way, leveraged beta (beta for investment in shareholders' equity or own capital beta) is determined both by the risk of the sector where the company operates and by the amount of assumed financial leverage risk.

The evidences of Rai study (2005) showed that (1) the company's systematic risk (beta) undergoes variations after issuing convertible debentures; (2) on average, variations are negative; but (3) heterogeneity of results in companies' analysis is significant, because nearly $40 \%$ have increases in beta. Additionally, variation in beta is significantly related to potential asset dilution as well as debt increase, but not significantly related to bond rating or declaration of fund use for issuing.

\section{METHODOLOGY}

This paper can be rated as a descriptive quantitative research, which describes the characteristics of a phenomenon seeking to discover the existence of association between variables. Secondary data were used with a view to analyzing the variations in systematic risk of convertible debenture issuing companies. Regarding means of investigation, ex post facto research technique was employed, where it is operated on facts that already occurred in the past, over which no control whatsoever is exercised.

Units of analysis were Brazilian publicly traded companies, listed on Bovespa, which have issued convertible debentures in shares registered with the CVM, between January 1998 and November 2006. The initial sample consisted of 39 issuing companies, totaling 44 issues in indicated period. 
Taking into account the absence of liquidity of share of 11 companies and the fact that 5 companies present a "canceled" status on Bovespa and 10 companies are not listed on Bovespa, the final sample consisted of 9 companies and 11 issues. Observation unit encompassed issuing deeds of convertible debentures, quotation of companies' shares during the period of interest, in addition to general capital market information that is related to researched phenomenon.

Concerning the investigation of the company's systematic risk variation, the beta of leveraged companies, according to Rai (2005), under the assumption of non-existence of riskfree rates and assets, leveraged beta and non-averaged beta may be related by the equation (1):

$$
\beta_{L}=(1+L) \beta_{U}, \text { or further: } \quad \Delta \beta_{L}=(1+L) \Delta \beta_{U}+\Delta L \beta_{U}
$$

$\beta_{L}$ being averaged company's beta (estimated by using the market model, expressed in equation (3) next), $L$ is company's financial leverage (given by the ration between debts and total capital) and $\beta_{u}$ non-leveraged company's beta with the same cash flow. According to Ross et al (2002), designating the sources of systemic risk by $F$ (factors), the factorial model of $k$ factors generates the rate of return of each bond, according to the following equation:

$$
R_{i}=\bar{R}+\beta_{1} F_{1}+\beta_{2} F_{2}+\ldots+\beta_{k} F_{k}+\varepsilon_{i}
$$

Where $\varepsilon_{i}$ is specific to a certain bond and is not related to the term of other bonds. Ross et al (2002) emphasize that, in practice, researchers often use a single factor model, using a stock market index as a single factor, as market portfolio observed return. Thus, market model is expressed as:

$$
R_{i}=\bar{R}+\beta\left(\overline{R_{m}}-R_{m}\right)+\varepsilon_{i}
$$

Or further:

$$
R_{i}=\alpha+\beta R_{m}
$$

Where $\alpha$ and $\beta$ are coefficients estimated by the ordinary least squares method; $R_{i}$ is observed expected return value of bond $i$ and $R_{m}$, expected return value observed from market portfolio, alpha $(\alpha)$ being an intercept equal to:

$$
\alpha=\bar{R}-\beta \bar{R}_{m}
$$


Admitting that $R_{i}$ and $R_{m}$ have normal distribution, $\beta$ can be estimated from the following equation:

$$
\beta=\frac{\operatorname{Cov}\left(R_{i}, R_{m}\right)}{\operatorname{Var}\left(R_{m}\right)}
$$

Following the research method used by Rai (2005), in this research betas were obtained from the Ordinary Least Squares Method, through the Market Model, providing consistent estimates of main fixed parameters. Taking into account that non-stochastic regressors' assumption is clearly violated, only asymptomatic results can be proved. Under such assumptions, estimators are asymptomatically normal:

$$
\hat{\beta}_{1 i} \sim A N\left(\beta_{1 i}, \sigma_{1 i}{ }^{2}\right) \quad \text { and } \quad \hat{\beta}_{2 \mathrm{i}} \sim A N\left(\beta_{2 i}, \sigma_{2 i}{ }^{2}\right)
$$

Where $\hat{\beta}_{1 i}\left(\hat{\beta}_{2 i}\right)$ is estimated beta in pre-issue (post-issue), $\beta_{1 i}\left(\beta_{2 i}\right)$ is true beta in pre-issue (post-issue) and $\sigma_{1 i}{ }^{2}\left(\sigma_{2 i}{ }^{2}\right)$ is beta variance in pre-issue (post-issue). In this manner, it can be said that variations in estimated betas provides a consistent estimate of the variation in true beta and has asymptomatic normal distribution with variance equal to the sum of variances of each estimate. Additionally, since pre- and post-issue beta estimations are built from independent observations, covariance will be nil. Therefore, we have that:

$$
\Delta \hat{\beta}_{L}=\hat{\beta}_{2 i}-\hat{\beta}_{1 i} \approx A N\left(\beta_{2 i}-\beta_{1 i}, \sigma_{1 i}^{2}, \sigma_{2 i}^{2}\right)
$$

Since $\sigma_{1 i}{ }^{2}$ and $\sigma_{2 i}{ }^{2}$ are not known, their estimates can be used as $S_{1 i}{ }^{2}=$ variance of $\beta_{1 i}$ and $S_{2 i}{ }^{2}=$ variance of $\beta_{2 i}$. Such results are used to build statistical tests for hypotheses related true beta of companies. Data analyzed in this paper consist of a sample of 44 primary convertible debenture issues of 39 distinct companies, in the period from January 1998 to December 2006, it being that in 2005 and 2006 there was no issuing of convertible debentures into shares, according to data available on CVM - Securities and Exchange Commission website.

Using as zero date registration date $(\mathrm{t}=0)$, Market Model for pre-issue trading days $(\mathrm{t}$ $=-150$ to -16 and post-issue $(\mathrm{t}=+16$ to +151$)$ was estimated. Pre-issue and post-issue market betas were estimated for each company ( $\beta_{1 i}$ and $\beta_{2 i}$, respectively), as well as variances $\left(S_{1 i}{ }^{2}\right.$ and $S_{2 i}{ }^{2}$, respectively). The main hypothesis tested in research development refers to a variation in beta, other than zero, for each company, being $\mathrm{H}_{0}: \Delta \hat{\beta}_{L}=0$ and $\mathrm{H}_{1}: \Delta \hat{\beta}_{L} \neq 0$. In 
order to test the hypothesis, test $t$ was performed, assuming that each beta variation observation is independent, with normal distribution. In order to perform companies' financial analysis, some financial indexes, separated by groups, were researched on Economática database, as described in Chart 1.

\begin{tabular}{|c|c|}
\hline Indicators & Brief Concept \\
\hline $\begin{array}{l}\text { Capital Structure } \\
\text { Fixed Assets PL } \\
\text { Interest in Third Party Capital } \\
\text { Composition of Indebtedness }\end{array}$ & $\begin{array}{l}\text { They are indexes that point out company asset financing source } \\
\text { composition, which may originate from own capital, such as from } \\
\text { partners or shareholders; from generated profits; or further, from third } \\
\text { party capital, such as loans and issuing debt bonds. }\end{array}$ \\
\hline $\begin{array}{l}\text { Liquidity } \\
\text { General Liquidity } \\
\text { Current Liquidity } \\
\text { Dry Liquidity }\end{array}$ & $\begin{array}{l}\text { They are important indexes to help search the answer to one of the } \\
\text { main questions about the company's situation, which is related to its } \\
\text { ability to honor its short and long-term commitments. }\end{array}$ \\
\hline $\begin{array}{l}\text { Medium Terms - Cycles } \\
\text { PMRE (Days) } \\
\text { PMPC (Days) } \\
\text { PMRV (Days) } \\
\text { Financial Cycle (Days) } \\
\text { Operational Cycle (Dias) }\end{array}$ & $\begin{array}{l}\text { Given that companies' Balance Sheet represents a kind photograph of } \\
\text { their equity structure, an analysis of how company dynamics between } \\
\text { two years occurs becomes useful. So-called medium-term indexes } \\
\text { reflect a little of this company dynamics. }\end{array}$ \\
\hline $\begin{array}{l}\text { Profitability } \\
\text { Asset Turnover } \\
\text { Net Margin } \\
\text { Return on Asset } \\
\text { Return on PL }\end{array}$ & $\begin{array}{l}\text { They are indexes aimed at measuring the success and efficiency of } \\
\text { companies in using their sources of financing (own capital and third } \\
\text { party capital) and in profit generation. They are useful to assess the } \\
\text { ability of companies to have profit in future years, to survive in long } \\
\text { term, attract financing, pay their creditors or even compensate their } \\
\text { shareholders. }\end{array}$ \\
\hline
\end{tabular}

\section{CHART 1: FINANCIAL INDEXES USED FOR ANALYZING COMPANIES}

Source: Adapted from Silva (2005).

Such analysis aims to highlight companies' financial situation in year of issue (zero date, considering record date) and in two subsequent years to issue, seeking to observe potential variations in the period. In Chart 2 , we have the period when indicators were consulted.

\begin{tabular}{|c|c|c|c|c|c|}
\hline Record Date & Issuer & Period & $\begin{array}{c}\text { Record } \\
\text { Date }\end{array}$ & Issuer & Period \\
\hline $01 / 08 / 98$ & Bicicletas Calói & 1996 to 2000 & $12 / 23 / 98$ & $\begin{array}{c}\text { Ripasa S.A. Celulose } \\
\text { e Papel }\end{array}$ & 1996 to 2000 \\
\hline $\begin{array}{c}2 / 19 / 199 \text { and } \\
10 / 26 / 99\end{array}$ & Paranapanema S/A & 1996 to 2001 & $02 / 05 / 99$ & $\begin{array}{c}\text { CERJ - Cia. } \\
\text { Eletricidade RJ } \\
\text { (Ampla Energia) }\end{array}$ & 1997 to 2001 \\
\hline $\begin{array}{c}8 / 17 / 98 \text { and } \\
09 / 02 / 99\end{array}$ & $\begin{array}{c}\text { Cia. Brasileira de } \\
\text { Distribuição }\end{array}$ & 1996 to 2001 & $12 / 24 / 99$ & Globo Cabo (Net) & 1997 to 2001 \\
\hline $10 / 21 / 98$ & $\begin{array}{c}\text { Cia. Força e Luz e } \\
\text { Cataguases }\end{array}$ & 1996 to 2000 & $07 / 26 / 00$ & $\begin{array}{c}\text { Brasil Telecom Part. } \\
\text { S/A }\end{array}$ & 1998 to 2002 \\
\cline { 4 - 6 } & & $04 / 23 / 01$ & Inepar S/A & 1999 to 2003 \\
\hline
\end{tabular}

CHART 2: COMPANIES' FINANCIAL ANALYSIS PERIOD

Source: Prepared by Authors 
For interpretation of companies' medium-term indicators, we further emphasize the importance of the relation between operational (PMRE + PMRV) and financial (PMRE + PMRV - PMPC) cycles, PMPC being purchasing payment medium-term, PMRE inventory renewal medium term; and PMRV sales receiving medium term. Figure 1 shows the difference existing between the negative financial cycle and positive financial cycle. A greater PMPC indicates a greater term for payment of suppliers, which could favor the occurrence of a negative financial cycle, reconciling with shorter PMRE and PMRV, in other words, a lower operational cycle, which may be financed by the financial cycle.

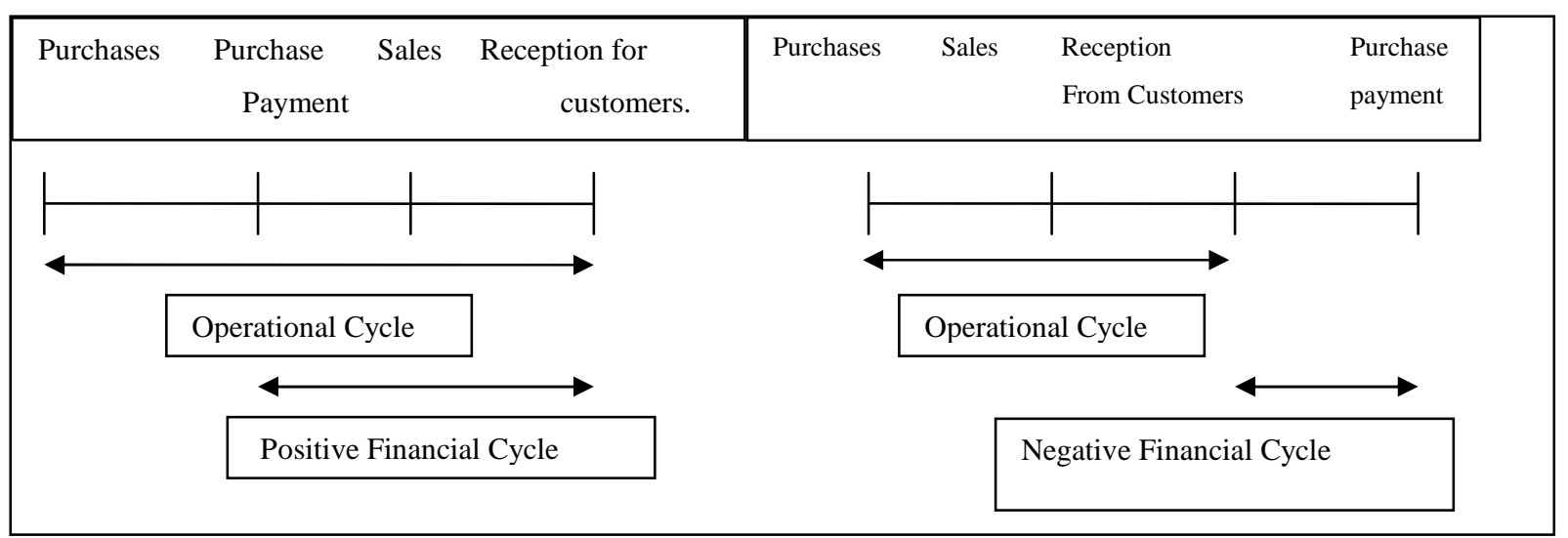

Figure 1: Positive and Negative Financial Cycle Source: Adapted from Silva (2005).

\section{PRESENTATION AND ANALYSIS OF RESULTS}

\subsection{Analysis of pre- and post-issue beta variation of convertible debentures}

For pre-issue $(\mathrm{t}=-150$ to -16$)$ and post-issue $(\mathrm{t}=+16 \mathrm{a}+151)$ beta estimation, quotation of shares of 39 issuing companies was necessary, totaling 44 issues between January 1998 to November 2006, in addition to IBOVESPA securities. Such data were researched with Economática and 11 companies did not present liquidity for their shares, in other words, long intervals with no quotations in analysis period occurred.

Furthermore, 5 companies were with "cancelled" status on BOVESPA (with quotations closed on prior periods to the maturity of issued convertible debentures); 10 companies were not found in the database and were not listed on BOVESPA and 4 companies, though they were listed on BOVESPA, had no quotation on Economática. In this manner, analysis of 9 companies was performed, which presented liquidity and had all data available, which encompassed the analysis of 11 issues.

The results of this analysis are presented in Table 1, where it can be verified that variations in beta were, mostly, positive. By analyzing pre-issue and post-issue betas, it can be 
seen that about $73 \%$ of the sample presented a considerable increase in beta after issuing convertible debentures.

The greatest observed percentage increase was of Globo Cabo, which passed from 0,006 to 0.12 , in other words, there was a $1900 \%$ increase. Companies Paranapanema S/A and Cia. Brasileira de Distribuição also presented a great positive variation in systematic risk, which increased by about $300 \%$ and $250 \%$, respectively. Beta reductions that occurred only encompassed three companies of the sample and were not significant to final results.

Table 1: Pre-Issue and Post-Issue Betas estimated by Market Model

\begin{tabular}{c|c|c|c}
\hline $\begin{array}{c}\text { Record } \\
\text { Date }\end{array}$ & Issuer & $\begin{array}{c}\text { Pre-Issue } \\
\text { Beta }\end{array}$ & Post-Issue Beta \\
\hline $01 / 08 / 1998$ & Bicicletas Calói & 0.0192 & 0.0149 \\
\hline $02 / 19 / 1998$ & Paranapanema S/A & 0.1810 & 0.7180 \\
\hline $08 / 17 / 1998$ & Cia. Brasileira de Distribuição & 0.6240 & 2.1750 \\
\hline $10 / 21 / 1998$ & Cia. Força e Luz Cataguases & 0.0360 & -0.0010 \\
\hline $12 / 23 / 1998$ & Ripasa S.A. Celulose e Papel & 0.0000 & 0.0030 \\
\hline $02 / 05 / 1999$ & CERJ - Cia. Eletricidade RJ (Ampla Energia) & 0.0290 & 0.0360 \\
\hline $09 / 02 / 1999$ & Cia. Brasileira de Distribuição & 0.7580 & 1.3010 \\
\hline $10 / 26 / 1999$ & Paranapanema S/A & -0.1950 & 0.1550 \\
\hline $12 / 24 / 1999$ & Globo Cabo (Net) & 0.0060 & 0.1200 \\
\hline $07 / 26 / 2000$ & Brasil Telecom Part. S/A & 0.8500 & 0.8580 \\
\hline $04 / 23 / 2001$ & Inepar S/A Ind. E Construções & 1.0870 & 1.5160 \\
\hline
\end{tabular}

Source: Prepared by Authors.

In order to test the alternative hypothesis that variation in beta would be different from zero (being $\mathrm{H}_{0}: \Delta \hat{\beta}_{L}=0$ ), test $\mathrm{t}$ was used, the results of which are expressed in Table 2 . At a $5 \%$ level of significance, test $t$ indicated that nil hypothesis can be rejected, pointing out that there was variation in companies' beta after issuing convertible debentures. Such variation was, on average, positive, in other words, the beta of issuing companies increased in postissue period, as can be observed in Table 2 next:

Table 2: T Test for hypothesis 1

\begin{tabular}{|c|c|c|}
\hline & Pre-Issue $\boldsymbol{\beta}$ & Post-Issue $\beta$ \\
\hline Average & 0.3086 & 0.6269 \\
\hline Variance & 0.1893 & 0.5690 \\
\hline Observations & 11 & 11 \\
\hline Pearson's Correlation & 0.8207 & \\
\hline Average difference hypothesis & 0 & \\
\hline Gl & 10 & \\
\hline Stat $\mathrm{t}$ & -2.2524 & \\
\hline $\mathrm{P}(\mathrm{T}<=\mathrm{t})$ uni-caudal & 0.0239 & \\
\hline $\mathrm{t}$ critical uni-caudal & 1.8124 & \\
\hline $\mathrm{P}(\mathrm{T}<=\mathrm{t})$ bi-caudal & 0.0479 & \\
\hline $\mathrm{t}$ critical bi-caudal & 2.2281 & \\
\hline
\end{tabular}

Source: Prepared by Authors.

This result, in spite of data restrictions for proposed statistical tests, is coherent with the absence of issuing convertible debentures into shares in 2005 and 2006 in the Brazilian 
Market. According to data of CVM (Securities and Exchange Commission), expressed in Table 3, issuing of simple debentures has been growing after Real Plan, on the other hand, convertible debentures have been losing space in Brazilian capital market over these years.

Table 3: Primary and secondary offerings registered with CVM

\begin{tabular}{c|c|c|c|c}
\hline \multirow{2}{*}{ Year } & Simple debentures & Amount of & Convertible Debentures & Amount of \\
\cline { 2 - 5 } & (R\$ thousand) & issues & $928,461.00$ & issues \\
\hline 1995 & $5,954,912.00$ & 73 & $1,353,195.00$ & 20 \\
\hline 1996 & $7,042,276.00$ & 83 & $1,477,007.00$ & 17 \\
\hline 1997 & $6,040,765.00$ & 40 & $3,381,092.00$ & 21 \\
\hline 1998 & $6,276,252.00$ & 41 & $1,592,000.00$ & 9 \\
\hline 1999 & $5,084,384.00$ & 29 & $1,435,000.00$ & 4 \\
\hline 2000 & $7,313,003.00$ & 38 & $586,844.00$ & 4 \\
\hline 2001 & $14,575,293.00$ & 37 & $64,600.00$ & 2 \\
\hline 2002 & $14,571,000.00$ & 23 & $68,900.00$ & 1 \\
\hline 2004 & $5,213,504.00$ & 16 & $633,642.00$ & 2 \\
\hline 2005 & $8,980,809.00$ & 36 & 0.00 & 0 \\
\hline 2006 & $41,538,852.00$ & 59 & 0.00 & 0 \\
\hline Total: & $\mathbf{1 2 2 , 5 9 1 , 0 5 0 . 0 0}$ & 47 & $\mathbf{1 1 , 5 2 0 , 7 4 1 . 0 0}$ & $\mathbf{9 6}$ \\
\hline Souryyyyy
\end{tabular}

Source: CVM (2006).

This study sought to validate for the Brazilian market, the perception existing in the American market that issuing convertible debentures would cause reduction in companies' systematic risk. The possibility of agency cost reduction by issuing convertible debentures was also highlighted by Simão (2006), although the author did not make a risk variation study. However, this research has shown that $77 \%$ of the sample companies, either did not present liquidity or were canceled, with quotations closed in period after issue and prior to the maturity of convertible debentures.

The finding of the absence of liquidity of issuing companies does not corroborate the conclusions obtained in American market studies referring to systematic risk reduction. In this manner, it can be said that the application of Rai1's study (2005) in the Brazilian capital market has indicate $\mathrm{d}$ that convertible debenture issuing companies in the period from 1998 to 2006, in their great majority, have no market liquidity.

\subsection{Analysis of sample companies' financial indicators}

Taking as zero date issuing registration date of convertible debentures, the indexes (which definitions were presented before in Table 1) of each analyzed company, sere obtained and analyzed, both of the two previous years and two subsequent years to zero date, totaling a five-year period. For those companies that had issues in distinct years, such as Parapanema S/A and Cia. Brasileira de Distribuição S/A, this was a six-year period, covering two prior 
and two subsequent years to both issues. In this manner, Tables 4 and 5 present indicators observed in analysis periods for each sample company, issue years being highlighted.

Table 4: Consulted indicators of sample companies - part 1

\begin{tabular}{|c|c|c|c|c|c|c|c|c|c|c|c|c|c|c|c|c|c|c|c|c|c|c|}
\hline \multirow{3}{*}{$\begin{array}{l}\text { Indicators } \\
\text { Fiscal Years }\end{array}$} & \multicolumn{22}{|c|}{ Issuing Companies } \\
\hline & \multicolumn{5}{|c|}{ Bicicletas Calói } & \multicolumn{6}{|c|}{ Paranapanema S/A } & \multicolumn{6}{|c|}{ Cia. Bras. Distribuição } & \multicolumn{5}{|c|}{ Ripasa } \\
\hline & 96 & 97 & 98 & 99 & 00 & 96 & 97 & \begin{tabular}{|c|}
98 \\
\end{tabular} & \begin{tabular}{|l|l|}
99 \\
\end{tabular} & 00 & 01 & 96 & \begin{tabular}{|l|l}
97 & \\
\end{tabular} & \begin{tabular}{|l|}
98 \\
\end{tabular} & 99 & 00 & 01 & 96 & 97 & \begin{tabular}{|l|l|}
98 \\
\end{tabular} & 99 & 00 \\
\hline \multicolumn{23}{|l|}{ Capital Structure } \\
\hline SE Imobilization & 96,9 & $-191,9$ & $-73,6$ & $-6,5$ & $-3,7$ & 3,6 & 0,7 & 0,6 & 0,3 & 0,4 & 1,2 & 98,8 & 107,0 & 143,0 & 76,9 & 85,7 & 84,7 & 115 & 117 & 124 & 110 & 84 \\
\hline Third Parties' Cap. Int. & 247 & -598 & -246 & -134 & -124 & 70,4 & 223,0 & 467,7 & 215,9 & 274,8 & 1087,9 & 15,1 & 17,0 & \begin{tabular}{|l|}
74,7 \\
\end{tabular} & -8 & 25 & 29 & 32,7 & 23 & 27 & 23 & \\
\hline Debt Comp. & 37,7 & 48,1 & 99,7 & 100,0 & 100,0 & 22,8 & 49,6 & 29,3 & 17,7 & 48,9 & 21,1 & 100 & 45,1 & 33,2 & 41,3 & 51,4 & 57,5 & 47,9 & 64,1 & 31,1 & 37,3 & 38,7 \\
\hline \multicolumn{23}{|l|}{ Liquidity } \\
\hline General Liquidity & 1,00 & 0,50 & 0,30 & 0,01 & 0,01 & 0,40 & 0,40 & 0,50 & 0,20 & 0,10 & 0,10 & 1,00 & 0,90 & 0,60 & 1,00 & 0,80 & 0,90 & 0,40 & 0,50 & 0,50 & 0,50 & 0,90 \\
\hline Current Liquidity & 1,80 & 0,90 & 0,40 & 0,01 & 0,01 & 0,70 & 0,10 & 0,20 & 0,70 & 0,20 & 0,30 & 0,90 & 1,30 & 1,10 & 1,60 & 1,10 & 1,20 & 0,60 & 0,80 & 0,70 & 0,70 & 1,30 \\
\hline Dry Liquidity & 1,10 & 0,40 & 0,20 & 0,01 & 0,01 & 0,70 & 0,10 & 0,20 & 0,70 & 0,20 & 0,30 & 0,70 & 1,00 & 0,80 & 1,30 & 0,80 & 0,90 & 0,40 & 0,60 & 0,50 & 0,50 & 1,00 \\
\hline \multicolumn{23}{|l|}{ Average Terms (Days) } \\
\hline PMRE & 92,2 & 106,7 & 46,9 & 7,7 & $\overline{15,3}$ & 10,3 & 8,1 & 0,0 & - & - & - & 26,9 & 34,8 & 38,9 & 42,2 & 53,0 & 42,9 & 54,0 & 62,0 & 67,2 & 62,1 & 59,2 \\
\hline PMPC & 52,2 & 67,0 & 95,4 & 0,7 & 3,7 & 12,3 & 18,1 & 105,7 & $=$ & - & - & 53 & 59,5 & 68,1 & \begin{tabular}{|l|}
66 \\
\end{tabular} & 70 & \begin{tabular}{|c|}
51 \\
\end{tabular} & 34,1 & 33,1 & 69,5 & \begin{tabular}{ll|}
38,6 \\
\end{tabular} & 45,6 \\
\hline PMRV & 103,5 & 43,3 & 69,2 & 10,9 & 36,7 & 51,0 & 102,9 & 6,5 & - & - & - & 43,3 & 44,5 & 38,4 & 33,1 & 28,1 & 32,9 & 87,6 & 111,0 & 94,5 & 81,1 & $\overline{77,1}$ \\
\hline Financial Cycle & 143,4 & 83,0 & 50,8 & 17,9 & 48,3 & 49,0 & 93,0 & $-99,2$ & - & - & - & 17,4 & \begin{tabular}{|c|}
19,8 \\
\end{tabular} & 9,2 & 9,0 & 10,9 & 24,6 & 108 & 140 & 92,2 & 105 & 91 \\
\hline Operating Cycle & 195,6 & 150,0 & 146,2 & 18,6 & $\overline{52,0}$ & 61,3 & 111,0 & 6,5 & - & - & - & 70,2 & \begin{tabular}{|l|}
79,3 \\
\end{tabular} & 77,3 & 75,3 & 81,1 & 75,8 & 142 & 173 & 162 & 143 & 136 \\
\hline \multicolumn{23}{|l|}{ Profitability } \\
\hline Assets Working & 1,10 & 1,30 & 1,20 & 1,40 & 0,40 & 0,10 & 0,10 & 0,00 & - & 0,00 & 0,00 & 2,10 & 1,50 & 1,40 & 1,10 & 1,00 & 1,00 & 0,30 & 0,30 & 0,30 & 0,40 & 0,50 \\
\hline Net Margin & $-4,60$ & $-51,30$ & $-47,30$ & $-65,80$ & $-192,30$ & $-105,40$ & $-470,40$ & $-527,00$ & - & & & 4,10 & 4,60 & 3,60 & 1,10 & 4,80 & 3,50 - & $-13,80$ & $-10,70$ & $-16,40$ & \begin{tabular}{ll|l}
16,60 & 1 \\
\end{tabular} & 19,40 \\
\hline Return w/o Assets & $-5,00$ & $-66,60$ & $-59,00$ & $-92,30$ & $-82,80$ & \begin{tabular}{|l|}
$-7,80$ \\
\end{tabular} & $-46,70$ & \begin{tabular}{|l|}
$-5,40$ \\
\end{tabular} & - & $-7,70$ & $-18,20$ & 8,60 & \begin{tabular}{|l|}
6,90 \\
\end{tabular} & \begin{tabular}{|l|}
5,30 \\
\end{tabular} & 1,20 & 5,00 & 3,50 & $-4,10$ & $-3,20$ & \begin{tabular}{|l|}
$-5,30$ \\
\end{tabular} & \begin{tabular}{ll|l}
7,50 & 1 \\
\end{tabular} & 10,10 \\
\hline Return w/o SE & $-16,10$ & & & & & $-13,20$ & $-150,80$ & $-30,80$ & - & $-28,70$ & $-215,70$ & 22,90 & 20,10 & 17,40 & 3,80 & 12,60 & 7,90 & $-6,00$ & $-5,10$ & \begin{tabular}{|l|}
$-8,50$ \\
\end{tabular} & \begin{tabular}{ll|l}
$13,70 \mid$ & 1 \\
\end{tabular} & 15,80 \\
\hline
\end{tabular}

Source: Prepared by Authors.

Table 5: Consulted indicators of sample companies - part 2

\begin{tabular}{|c|c|c|c|c|c|c|c|c|c|c|c|c|c|c|c|c|c|c|c|c|}
\hline \multirow{2}{*}{ Indicators } & \multicolumn{20}{|c|}{ Issuing Companies } \\
\hline & \multicolumn{5}{|c|}{ CERJ } & \multicolumn{5}{|c|}{ Globo Cabo (Net) } & \multicolumn{5}{|c|}{$\begin{array}{l}\text { Brasil Telecom } \\
\end{array}$} & \multicolumn{5}{|c|}{ Inepar S/A } \\
\hline Fiscal Years & 97 & 98 & 99 & 00 & 01 & 97 & 98 & 99 & 00 & 01 & 98 & 99 & 00 & 01 & 02 & 99 & 00 & \begin{tabular}{|l|l|}
01 \\
\end{tabular} & \begin{tabular}{|l|}
02 \\
\end{tabular} & 03 \\
\hline \multicolumn{21}{|l|}{ Capital Structure } \\
\hline SE Imobilization & 327 & 312 & 440 & 334 & 775 & 0,1 & 1,2 & 1,5 & 14,2 & 28,4 & 127 & 130 & 124 & 151 & 141 & 15,3 & 27,1 & \begin{tabular}{|l|}
49,8 \\
\end{tabular} & 233 & -153 \\
\hline Third Parties' Cap. Int. & 121 & 220 & 244 & 162 & 300 & 91,1 & 108 & 148 & 395 & 356 & 43,6 & 51,7 & 74,8 & 105 & \begin{tabular}{|l|}
119 \\
\end{tabular} & 58,8 & \begin{tabular}{|l|}
155 \\
\end{tabular} & 299 & 2169 & -2680 \\
\hline Debt Comp. & 34,8 & 82,6 & 9,1 & 33,0 & 48,7 & 0,6 & 1,3 & 60,2 & 18,0 & 16,1 & 49,0 & 78,2 & 39,0 & 13,2 & 13,4 & 60,9 & \begin{tabular}{|l|}
80,8 \\
\end{tabular} & \begin{tabular}{|l|}
79,3 \\
\end{tabular} & \begin{tabular}{|l|}
75,1 \\
\end{tabular} & 81,1 \\
\hline \multicolumn{21}{|l|}{ Liquidity } \\
\hline General Liquidity & 0,20 & 0,40 & 0,40 & 0,50 & 0,50 & 1,70 & 1,10 & 1,20 & 0,80 & 0,80 & 0,40 & 0,40 & 0,50 & 0,40 & 0,60 & 1,00 & \begin{tabular}{|l|}
0,90 \\
\end{tabular} & \begin{tabular}{|l|}
0,70 \\
\end{tabular} & 0,70 & 0,70 \\
\hline Current Liquidity & 0,60 & 0,90 & 0,80 & 0,50 & 0,40 & 4,20 & 0,10 & 0,40 & 0,70 & 0,20 & 0,40 & 0,40 & 0,80 & 0,80 & 1,30 & 1,00 & \begin{tabular}{|l|}
0,90 \\
\end{tabular} & \begin{tabular}{|l|}
0,60 \\
\end{tabular} & 0,50 & $\overline{0,50}$ \\
\hline Dry Liquidity & 0,60 & 0,90 & 0,80 & 0,50 & 0,40 & 4,20 & 0,10 & 0,40 & 0,70 & 0,20 & 0,40 & 0,40 & 0,80 & 0,80 & 1,30 & 0,80 & \begin{tabular}{|l|}
0,80 \\
\end{tabular} & \begin{tabular}{|l|}
0,50 \\
\end{tabular} & 0,40 & $\overline{0,30}$ \\
\hline \multicolumn{21}{|l|}{ Average Terms (Days) } \\
\hline PMRE & & & & & & & & & & & 4,0 & 0,8 & 1,6 & 0,8 & 1,9 & 110 & 85 & 68 & 60 & 107 \\
\hline $\begin{array}{l}\text { PMPC } \\
\end{array}$ & & & & & & & & & & & 124 & 47,9 & 117 & 109 & 76 & 116 & 86 & 52 & 45 & 60 \\
\hline PMRV & & & & & & & & & & & 66,4 & 59,6 & 118,5 & 80,3 & 86,3 & 128 & 263 & 135 & 147 & 182 \\
\hline Financial Cycle & & & & & & & & & & & $-53,8$ & 12,5 & 3,1 & $-27,9$ & 12,3 & 121 & 261 & 151 & 161 & 230 \\
\hline Operating Cycle & & & & & & & & & & & 70,4 & 60,4 & 120,1 & 81,1 & 88,2 & 238 & 348 & 202 & 206 & 289 \\
\hline \multicolumn{21}{|l|}{ Profitability } \\
\hline Assets Working & 0,60 & 0,40 & 0,30 & 0,40 & 0,40 & 0,01 & 0,01 & 0,01 & 0,01 & 0,01 & 0,30 & \begin{tabular}{|l|l|}
0,40 \\
\end{tabular} & 0,30 & 0,40 & 0,50 & 0,10 & \begin{tabular}{|l|l|}
0,30 \\
\end{tabular} & \begin{tabular}{|l|l|}
0,50 \\
\end{tabular} & \begin{tabular}{|l|}
0,40 \\
\end{tabular} & 0,20 \\
\hline Net Margin & 4,70 & 6,50 & $-5,60$ & 0,50 & $-3,50$ & & -7916 & -2027 & -846 & -2624 & 12,60 & $-4,70$ & 11,80 & 4,60 & 6,20 & -163 & \begin{tabular}{|l|}
$-76,4$ \\
\end{tabular} & \begin{tabular}{|l|l}
$-25,9$ \\
\end{tabular} & \begin{tabular}{|l|l|} 
& $-48,4$ \\
\end{tabular} & 36,6 \\
\hline Return w/o Assets & 2,80 & 2,40 & $-1,90$ & 0,20 & $-1,40$ & $-17,9$ & $-30,5$ & $-47,6$ & $-26,5$ & $-46,4$ & 4,00 & $-1,80$ & 3,60 & 2,00 & 2,90 & $-21,7$ & \begin{tabular}{|l|}
$-23,5$ \\
\end{tabular} & \begin{tabular}{|l|}
$-13,4$ \\
\end{tabular} & \begin{tabular}{|l|}
$-19,5$ \\
\end{tabular} & $-11,5$ \\
\hline Return w/o SE & 11,90 & 17,10 & $-16,30$ & 1,50 & $-16,90$ & $-30,0$ & $-84,9$ & \begin{tabular}{|c|}
-162 \\
\end{tabular} & -128 & -259 & 5,70 & \begin{tabular}{|l|}
$-2,70$ \\
\end{tabular} & \begin{tabular}{l|l}
6,30 \\
\end{tabular} & 4,10 & 6,30 & $-34,4$ & \begin{tabular}{|l|}
$-60,0$ \\
\end{tabular} & \begin{tabular}{|l|}
$-60,6$ \\
\end{tabular} & \begin{tabular}{|l|}
-442 \\
\end{tabular} & $-8,8$ \\
\hline
\end{tabular}

It is pointed out that only Cia. Força e Luz Cataguazes cannot be analyzed, taking into account that indicators were not found in Economática database and, additionally, data about medium-term indicators of Paranapanema S/A, CERJ and Globo Cabo were not available for all analyzed period years.

According to financial situation indicators, including liquidity and capital structures, the companies, generally speaking, present low liquidity rates in analyzed periods, which indicates low payment ability, both short term and long term. Furthermore, a drop in liquidity is verified in convertible debenture post-issue periods. About indebtedness, third party capital 
participation in relation to own resources, revealed to be, in most companies, quite high, which may indicate an unfavorable debt profile, with pressure on cash flow and financial management difficulties.

In relation to resource management indicators, positive financial cycles, with long term stand out. In other words, it was verified, in most companies, along period comprised between payment of supplies and credit sale receptions, which may represent a small portion of investments in asset turnover.

Most companies presented low PMPC and high PMRE and PMRV, resulting in positive financial cycles, which is unfavorable to the company, because it represents greater financing with own resources of operational cycle, which could be financed by suppliers, if terms were more favorable to companies.

Finally, profitability indicator analysis released low asset turnover in all companies, which is in keeping with observed net margin rates, which were also low and presented a drop in the period. The high incidence of negative profitability indicators, such as negative net margin and returns on assets and negative shareholders' equity, indicates that the companies, in their great majority, presented loss in analyzed years. As explained before, such indicators translate the success of companies in using their sources of financing, being useful to assess profit generation capacity of such companies.

This being the case, low profitability rates of convertible debenture issuing companies, observed in concerned period, may reveal the cumulative effect of low liquidity and poor asset and capital structure management, representing a low profitability and economic efficiency of a set of policies and decisions made by companies .

These results confirm the conclusions of Kimura (2003), who conducted a study seeking the verify that choosing the company issuing a certain type of debentures (simple or convertible) would have relation to its structure of short-term assets and liabilities and their operating and financial performance aspects.

The results of his study showed evidences that more indebted companies tend to promote financing of their activities by means of convertible bonds. This would occur since the possibility of conversion would allow reducing leverage when necessary. The author further suggested that issuing convertible debentures would be more used by companies with short-term debts proportionately greater, taking into account that conversion transforms third party capital into own capital, in other words, into resources with longer maturity dates. 


\section{CONCLUSION}

Results found give rise to some valid discussions about the convertible debenture market into shares in Brazil, in keeping with their current stage of development. First, financial conditions of convertible debenture issuing companies in analyzed period stand out, which revealed to be precarious and, oftentimes, pointing out high risk of bankruptcy. This verification results from the empirical finding of absence of liquidity of companies, with cases of quotation closing by cancelation of some registrations on Bovespa. There are further evidences that many companies that issued convertible debentures, although open, have no shares issued by them traded on the stock exchange.

Furthermore, the analysis of financial indicators reveals the failure of sample companies in using their sources of financing and profit generation. Through this analysis, it was verified that companies present low activity and liquidity rates, low profitability, high financial dependence and ineffective resource management. This reality reveals that convertible debentures tend to be used by companies with precarious financial situation. Furthermore, they may be associated with the high volatility of Brazilian economy, which may have harmed companies that sought financing by issuing convertible debentures. It is emphasized that volatility in the real sector of the economy makes business in Brazil more risky, affects credit risk and creates situations that may encourage the conflict between creditors and shareholders and, consequently, breach of contracts.

The positive impacts on post-issue betas of sample companies, indicate an increase in companies' systematic risk, which evidences the informational character of debenture issuing decisions. According to Deangelo and Masulis (1980), Debenture issuing reflex on the return and risk of companies' shares may be both positive and negative. Debenture issuing may signal the need for outside financial resources and, so, may be interpreted by the market as bad news. On the other hand, signaling perceived by the market may be related to financial leverage increase, representing bad news. The conclusions of this study are in keeping with the hypothesis that the company, when issuing convertible debentures, signals unfavorable prospects, by the need to resort to new outside funds, revealing inability to obtain resources by retaining earnings and/or cutting expenses and/or selling assets.

Taking into account results found, for future studies, analysis of signaling given to the market by issuing convertible debentures is suggested.

Another important point to be discussed is related to misuse of the bond on the domestic market. Results found warn not only about the true purposes of issues on the 
primary debenture market, as well as to the absence of transparence on the secondary market. Convertible debentures could provide advantages to shareholders and bond bearers. Potential advantages of debenture holders are associated with the possibility of gain in conversion. Whereas the company and its shareholders have a lot to gain with long-term financing cost reduction, due to the possibility of a less burdensome cash flow in comparison to a simple debenture, since hybrid bond remuneration is lower than a simple bond.

Additionally, since the convertible debenture can be used o restructure the company's liabilities, it might reduce its level of indebtedness by conversion into shares and, so, expand the company's financial flexibility. Such benefits are not verified in practice, a conclusion that can be extracted both from data about the effectiveness of conversion in Brazil, and the expressive and growing issuing reduction over the years and financial conditions presented by issuing companies.

\section{REFERENCES}

ANDIMA; ABRASCA. O Que são debêntures. jun. 2002. Disponível em:

<http://www.Andima.com.br>, <http://www.Abrasca.org.br>.

BOVESPA. Guia Bovespa de debêntures. São Paulo: BOVESPA, 2003. Disponível em: <http://www.bovespa.com.br>.

BRIGHAM, Eugene F.; EHRHARDT, Michael C. Administração financeira: teoria e prática. São Paulo: Pioneira Thomson Learning, 2006.

CVM. Comissão de Valores Mobiliários. 2006. Disponível em: 〈http://www.cvm.gov.br〉. Acesso em: 23 mar. 2007.

DAMODARAN, Aswath. Finanças corporativas: teoria e prática. 2. ed. Porto Alegre: Bookman, 2004.

DEANGELO, Harry; MASULIS, Ronald W. Optimal capital structure under corporative and personal taxation. Journal of Financial Economics, v. 8, p. 3-29, 1980.

FILGUEIRA, A. L. L.; LEAL, R. P. C. Análise de cláusulas de escrituras de debêntures brasileiras após a estabilização econômica. In: LEAL, R. P. et al. (Org.). Finanças corporativas. São Paulo: Atlas, 2000. p. 97-115.

FILGUEIRA, A. L. L. Mercado de debêntures no Brasil: estágio atual e desafios ao desenvolvimento. Cadernos Discentes COPPEAD, Rio de Janeiro, n. 28, p. 4-36, 2006.

HULL, John C. Opções, futuros e outros derivativos. 3. ed. São Paulo: Bolsa de Mercadoria \& Futuros, 1998. 
KIMURA, H. Evidências empíricas de aspectos determinantes do tipo de debênture em emissões no mercado brasileiro. In: SEMINÁRIOS EM ADMINISTRAÇÃO (SEMEAD), 6., 2003, São Paulo (SP). Anais... São Paulo: FEA/USP, 2003.

LELAND, H.; PYLE, D. Information asymmetries, financial structure and financial intermediaries. Journal of Finance, v. 32, p. 371-387, 1977.

LEWIS, C. M.; ROGALSKI, R. J.; SEWARD, J. K. Understanding the Design of Convertible Debt. Journal of Applied Corporate Finance, v. 11.1, p. 45-53, 1998. .; ___ . . Risk changes around convertible debt offerings. Journal of Corporate Finance, v. 8, p. 67-80, 2002.

MATOS, João Amaro de. Theoretical foundations of corporate finance. Princeton: Princeton University Press, 2001.

MAYERS, D. Why firms issue convertible bonds: the matching of financial and real investment options. Journal of Financial Economics, v. 15, p. 83-102, 1998.

MYERS, S. MAJLUF, N. Corporate financing and investment decisions when firms have information that investors do not have. Journal of Finance Economics, v. 13, p. 187-221, 1984.

PROCIANOY, J. L.; VEISMAN, E. Debêntures conversíveis em ações e o mercado de capitais brasileiro: revisão e novos questionamentos. In: LEAL, R. P. et al. (Org.). Finanças corporativas. São Paulo: Atlas, 2000. p. 81-96.

RAI, A. Changes in risk characteristics of firms issuing hybrid securities: case of convertible bonds. Accounting and Finance, v. 45, p. 635-651, 2005.

RIBEIRO, Andréa Masagão. Desenvolvimento do mercado de debêntures: avaliação do caso brasileiro. 2002. 97 f. Dissertação (Mestrado em Administração de Empresas) Programa de Pós-Graduação da Fundação Getúlio Vargas (FGV), Escola de Administração de Empresas de São Paulo, São Paulo, 2002.

ROSS, S. A.; WESTERFIELD, R. W.; JAFFE, J. F. Administração financeira: corporate finance. 2. ed. São Paulo: Atlas, 2002.

ROZENBAUM, Sérgio. As Debêntures conversíveis em ações podem ser um instrumento financeiro eficaz na captação de recursos a longo prazo para as empresas brasileiras. 2004. 136 f. Dissertação (Mestrado em Administração de Empresas) - Programa de PósGraduação do Departamento de Administração, Pontifícia Universidade Católica (PUC-RJ), Rio de Janeiro, 2004.

SILVA, José P. da. Análise financeira das empresas. 7. ed. São Paulo: Atlas, 2005.

STEIN, J. Convertible bonds as backdoor equity financing. Journal of Financial Economics, v. 32, p.3-21, 1992. 
SIMÃO, Jorge Carlos Menezes. Apreçamento de debêntures conversíveis e as perspectivas dos títulos híbridos no mercado de capitais brasileiro: um estudo de casos. 2006. 249 f. Dissertação (Mestrado em Administração de Empresas) - Programa de PósGraduação da Fundação Getúlio Vargas (FGV-SP), São Paulo, 2006.

SND. Sistema Nacional de Debêntures. Informações ao mercado. Disponível em: <http://www.debentures.com.br>. Acesso em: 23 jun. 2007.

TIROLE, Jean. The Theory of corporate finance. Princeton: Princeton University Press, 2005. 